\title{
Satisfaction towards Homeopathy Treatment among General Public in Tamil Nadu, India
}

\author{
V. Vetriselvan, G. Yoganandan
}

\begin{abstract}
In the current scenario, homeopathy is a medical system that is growing rapidly and is being practiced in almost all over the world. Homoeopathy is 200 years old system of medicine. The need of the study will help the general public and society to have a look on future prospects on homeopathy. This study focuses on primary data. Collected from the general public, people of the society. The well structured questionnaire is formulated by interview method, the data stays collected. Nonprobability convenience sampling is used to collect responses. The researcher personally collected data. Properconcern is taken to ensure that the questionnaire is filled in correctly. Finally, 130 complete questionnaires used for data analysis purposes. The standard questionnaire was adapted.
\end{abstract}

Keywords: Awareness, Consumer Satisfaction, Homeopathy Treatment, Traditional Medicine

\section{INTRODUCTION}

In the current scenario, homeopathy is a medical system that is growing rapidly and is being practiced in almost all the world (AYUSH, 2016)[1]. Homoeopathy is 200 years old system of medicine. Homoeopathy was first developed by the German physician Samuel Hahnemann in 1810. Homoeopathy remedies excite the body's own protected and defensestructure to bring about healing (Birgit, 2010)[2]. It is used in small doses, particularly prepared remedies to set the body's systems lower back so as and stimulate a person's personal energies in the direction of a natural recovery manner (Yoganandan \& Vetriselvan, 2017)[18]. "Traditional" remedy is a gadget of medication that has been practiced in united states of America over decades, while "complementary and opportunity" medicinal drug (CAM) refers to a traditional device of drugs that is practiced in places, like Tibetan medication whilst practiced in India(Naicker, 2008)[13]. Traditional medicine includes diverse fitness practices, tactics, expertise and beliefs. It frequently integrates indigenous plant, animal and mineral primarily based drug treatments (Roy, 2015)[15].

\section{CONSUMER SATISFACTION}

It is noteasy to recognize and satisfy the consumers' needs, expectations and behavior, and knowing them doesn't guarantee achievement in the marketplace, because client behaviour isn't always rational (Riley, etall.2001)[14]. Among the strategies, that can verify the patron pride of purchase or carrier, ordinary technique which might enable to express this problem in a complete manner.

Revised Manuscript Received on December 05, 2019.

* Correspondence Author

V. Vetriselvan*, Periyar Institute of Management Studies, Periyar University, Salem, India. Email: vetriimoa@gmail.com

Dr. G. Yoganandan, Periyar Institute of Management Studies, Periyar University, Salem, India. Email: g_yoganandan@yahoo.com
At its base there's a concept of needs and pleasurable. Various knowledge of the wishes and emotional states related to them leads to an alternate remedy of pleasure, and to a exclusive method to its measurement. (Mcmahon \& Forehand,2019)[11].

\section{THE CONCEPT OF CONSUMER SATISFACTION}

The presence of many companies in the market is conditioned by a number of satisfied customers. The customer is the main aspect of being in the market.It is obvious then, that firms, which need to face the opposition, want to provide valuable and precise phrases to their customers, that will satisfy their wants(Shaffer \& Sherrell)[16]. This fulfillment includes not only the thoughtsconnected with the shopping method, but also the environment earlier then and after the carrying outpurchase (Devid, 2014)[5]. If the business enterprise brings itself nearer for customers, it is less difficult tocomplete their needs and dreams for in an extended length of time.Therefore, a importantthing ofconstructing a long-term achievement is ongoing andsatisfyingconsumer's needs. Customer pleasure is often related to the patron gratification. Products or services, which might be a source of pleasure, provide the suitable price to their customers, as a minimum in a sufficient degree(Hsu, et all.,2012)[8]. Standard ISO 10004 specifies that: "Satisfaction is a judgment, an opinion expressed via the patron. The diploma of pride reflects the space among the consumer's vision ofthe predicted product, and the patron'sperception of the added product(Newsome \& Wright, 1999)[12]. All decisions, made by means of the client, are affected by many elements, which include monetary ones, such as incomes, fee, savings, loans, and the impact of advertising devices, and noneconomic elements, along with: demographic, social or psychological ones. Recognizing and satisfying customer's needs, expectations, options and behavior isn't always smooth and it does not guarantee success on the market(Dnsc, 2019)[6]. The reason of that is the reality, that customer behaviour isn't always rational. Consumers, who make a buy of a positive true, commonly have already clarified requirements referring to its first-class, purpose or use(Biesok, 2017)[3]. They do not pay for the product in a physical experience, however they pay for price or what they assume from the product. Expectations havean exceptional scope and every now and then they may be very overstated or pretty modest. That's why taking a choice via the client is preceded by initiating and defining the Customer's unique needs(Kochkin, 2000)[10]. 


\section{THE BENEFITS OF CUSTOMER SATISFACTION}

Overall customer satisfaction must be more fundamental indicator of company performance because of its relation to behavioral and economic consequences that benefit the company. Internally, improving quality and customer satisfaction reduces expenses associated with damagesupplies and services (Coshall \& Combe, 2006)[4]. In most markets, the quality of service and satisfaction is asignificant consideration in a purchase decision. Studies have shown that customers place considerable value on the quality and responsiveness of an organization's service component, as well as product quality and availability, in making purchase decisions(Giese \& Cote, 2014)[7].

\section{LITERATURE REVIEW}

Ugur, Y., Martin, B., \&Uwe, S. (2004) carried out a titled "Relationships between service quality, background characteristics, and satisfaction and selected behavioural outcomes by using retail banking in Germany" pointed out that the service quality is present at the basis of buyer satisfaction and it is connected to such behavioural results such as word of mouth, criticism, commending and switching. However, various phases of service quality and changed customer features seem to be associated with different results. For illustration, the results suggest that tangible essentials of service quality and being a woman are more closely associated with positive word of mouth and commitment. Inferences of the results to make more customer satisfaction, to attain higher levels of favourable effects and to improve negative results.

Nimako (2012) in his study titled "Customer dissatisfaction and complaining responses towards mobile telephony services" Observed that the level of satisfaction and dissatisfaction is specific for complainers and noncomplainers the examine revealed that maximum commonplace complaining behaviour is to file whinge to the customer care, refraining from the usage of the offerings, and complaining to the mass media. This study contributes to the body of understanding of patron complaining conduct and patron pleasure. It specially presents empirical aid to the fact that dissatisfaction does not necessarily motive in complaining but even satisfied customers complain. It additionally presents empirical evidence on complaining responses of clients and the impact of consumer demographic variables on complaining responses.

Duodu and Amankwah (2011) conducted titled "An analysis and assessment of customer satisfaction with service quality in insurance industry in Ghana" Used convenient sampling method to gather facts from 1100 clients of 11 insurance companies. They considered price as a measurement of service excellent and said that rate does not positively affect customer satisfaction in Ghana's Insurance industry. It turned into determined that useful first-rate objects (most effective Reliability and Responsiveness) in part supported pride even as technical fine and photo of the carrier issuer does no longer considerably affect customer satisfaction. It became additionally found that client pleasure definitely impacts behavioural intensions of the customers.
Saha and Theingi (2009) in they out a study titled "Service quality, satisfaction, and behavioural intentions: A study of low-cost airline carriers in Thailand" and established the order of significance of the measurements of services quality specificallyjourney schedules, flight assistants, tangibles, and ground staff. Satisfied passengers remained mostly influenced through the schedule. Such customers engaged in confident word-of- mouth message and taken high re-buyersgoals. Dissatisfied passengers chosen to change airlines,rather than providing response to them.

\section{MATERIAL, METHODS AND MEASUREMENT}

In the light of the above discussion, this study aims at deconstructing the consumer satisfaction of homeopathy, from the research point of view of its general public. The need of the study will help the general public and society to have a look on future prospects towards homeopathy. Research design is descriptive research. Primary data is collected from general public, people of the society. The structured questionnairecollected. Population for this study is general public those who are using Homeopathy medicine. Since homeopathy users are unknown, Nonprobability convenience sampling is used to collect responses. The researcher personally collected data from four districts of Tamil Nadu such as Namakkal, Thiruvannamalai and Karur. From each district 50 respondents were taken. Properconcern is taken to ensure that the questionnaire is filled in correctly. A total of 150 responses were collected but twenty respondents were rejected because of incomplete replies. Finally, 130 complete questionnaires were used for data analysis purposes. The questionnaire used was adapted from, (Jaggi \& Ghosh, 2017)[9] and (Surywanshi \& Maharshi, 2013)[17], because of their previous success in gathering valuable data towards consumer satisfaction. The tools used in this study are Descriptive analysis, Analysis of Variance (ANOVA) and weighted average method.

\section{RESULTS AND DISCUSSION}

\section{A. Descriptive analysis}

\begin{tabular}{|c|c|c|c|}
\hline Particulars & $\begin{array}{c}\text { Demographic } \\
\text { Variables }\end{array}$ & $\begin{array}{c}\text { No.of } \\
\text { Respondents }\end{array}$ & $\%$ \\
\hline \multirow{2}{*}{ Gender } & Male & 84 & $65 \%$ \\
\hline & Female & 46 & $35 \%$ \\
\hline \multirow{4}{*}{ Age } & $18-25$ years & 43 & $33 \%$ \\
\hline & 25-30 years & 48 & $37 \%$ \\
\hline & $30-35$ years & 28 & $22 \%$ \\
\hline & $\begin{array}{c}\text { 35-40 years } \\
\text { Above }\end{array}$ & 11 & $9 \%$ \\
\hline
\end{tabular}




\begin{tabular}{|c|c|c|c|}
\hline \multirow{4}{*}{ Education } & School level & 6 & $5 \%$ \\
\cline { 2 - 4 } & UG & 14 & $11 \%$ \\
\cline { 2 - 4 } & PG & 38 & $29 \%$ \\
\cline { 2 - 4 } & Diploma level & 38 & $29 \%$ \\
\cline { 2 - 4 } & Others & 34 & $26 \%$ \\
\hline \multirow{4}{*}{$\begin{array}{c}\text { Monthly } \\
\text { Income }\end{array}$} & Below Rs.10000 & 9 & $7 \%$ \\
\cline { 2 - 4 } & Rs.10000-20000 & 19 & $15 \%$ \\
\cline { 2 - 4 } & Rs.20000-30000 & 26 & $20 \%$ \\
\cline { 2 - 4 } & Rs.30000-40000 & 48 & $37 \%$ \\
\cline { 2 - 4 } & Rs.40000 & 28 & $22 \%$ \\
\hline $\begin{array}{c}\text { Marital } \\
\text { Status }\end{array}$ & Married & 66 & $51 \%$ \\
\cline { 2 - 4 } & Unmarried & 64 & $49 \%$ \\
\hline \multirow{2}{*}{$\begin{array}{c}\text { Family } \\
\text { Type }\end{array}$} & Nuclear family & 65 & $50 \%$ \\
\cline { 2 - 4 } & Joint family & 65 & $50 \%$ \\
\hline Residential & Rural & 73 & $56 \%$ \\
\cline { 2 - 4 } Area & Urban & 57 & $44 \%$ \\
\hline
\end{tabular}

\section{Source: primary data}

Therefore, in the above demographic analysis, there is maximum number of male respondents in which most of them are within the age limit of 25-30. The maximum levels of qualification are PG and Diploma level. The majority of the respondents are monthly income Rs.30000 - 40000. The maximum respondents are married. The $50 \%$ of the family types are nuclear family and $50 \%$ of the family types are joint family and most of the respondent from rural areas. The effective treatment of medicines, the respondents said that the study of homeopathy medicines was necessary for the public people.

\section{B. ANOVA}

\begin{tabular}{|c|c|c|c|c|c|c|c|}
\hline Factor & $\begin{array}{l}\text { Partic } \\
\text { ulars }\end{array}$ & $\begin{array}{l}\text { Vari } \\
\text { ance }\end{array}$ & S.S & $\begin{array}{l}\mathbf{d} \\
\mathbf{f}\end{array}$ & M.S & فํ & $\begin{array}{l}\text { Ho } \\
\text { Acc } \\
\text { epte } \\
\text { d / } \\
\text { Reje } \\
\text { cted }\end{array}$ \\
\hline \multirow{5}{*}{ 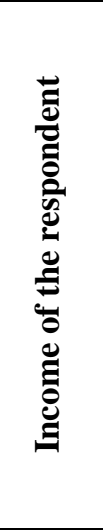 } & $\begin{array}{l}\text { below } \\
\text { Rs.100 } \\
00\end{array}$ & \multirow{2}{*}{$\begin{array}{c}\text { Betw } \\
\text { een } \\
\text { Grou } \\
\text { ps }\end{array}$} & \multirow{2}{*}{$\begin{array}{c}72.39 \\
98\end{array}$} & & \multirow{2}{*}{18.1} & \multirow{5}{*}{ de } & \multirow{5}{*}{$\begin{array}{c}\text { Null } \\
\text { Hyp } \\
\text { othe } \\
\text { sis } \\
\text { Acc } \\
\text { epte } \\
\text { d }\end{array}$} \\
\hline & $\begin{array}{l}\text { Rs. } 100 \\
00- \\
20000\end{array}$ & & & & & & \\
\hline & $\begin{array}{l}\text { Rs. } 200 \\
00- \\
30000 \\
\end{array}$ & \multirow{3}{*}{$\begin{array}{c}\text { Withi } \\
\text { n } \\
\text { Grou } \\
\text { ps }\end{array}$} & \multirow{3}{*}{$\begin{array}{c}1082 . \\
8\end{array}$} & 4 & \multirow{3}{*}{8.622} & & \\
\hline & $\begin{array}{l}\text { Rs.300 } \\
00- \\
40000 \\
\end{array}$ & & & & & & \\
\hline & Rs.400 & & & & & & \\
\hline
\end{tabular}

\begin{tabular}{|c|c|c|c|c|c|c|c|}
\hline & $\begin{array}{l}00 \\
\text { Above }\end{array}$ & & & & & & \\
\hline \multirow{4}{*}{ 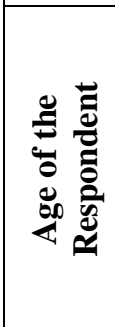 } & $\begin{array}{l}18-25 \\
\text { years }\end{array}$ & $\begin{array}{c}\text { Betw } \\
\text { een }\end{array}$ & 125.2 & \multirow{4}{*}{5} & 41.74 & \multirow{4}{*}{ 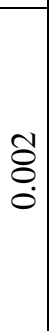 } & \multirow{4}{*}{$\begin{array}{l}\text { Null } \\
\text { Hyp } \\
\text { othe } \\
\text { sis } \\
\text { Reje } \\
\text { cted }\end{array}$} \\
\hline & $\begin{array}{l}25-30 \\
\text { years }\end{array}$ & $\begin{array}{c}\text { Grou } \\
\text { ps }\end{array}$ & 4 & & 65 & & \\
\hline & $\begin{array}{l}30-35 \\
\text { years }\end{array}$ & \multirow{2}{*}{$\begin{array}{c}\text { Withi } \\
\text { n } \\
\text { Grou } \\
\text { ps }\end{array}$} & \multirow{2}{*}{$\begin{array}{c}1029 . \\
96\end{array}$} & & \multirow{2}{*}{$\begin{array}{c}8.174 \\
29\end{array}$} & & \\
\hline & $\begin{array}{l}35-40 \\
\text { years }\end{array}$ & & & & & & \\
\hline \multirow{5}{*}{ 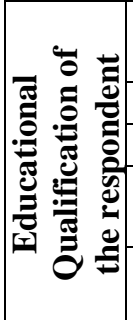 } & $\begin{array}{l}\text { school } \\
\text { level }\end{array}$ & $\begin{array}{c}\text { Betw } \\
\text { een }\end{array}$ & 140.3 & \multirow{5}{*}{4} & \multirow{3}{*}{$\begin{array}{c}35.07 \\
62\end{array}$} & \multirow{5}{*}{$\begin{array}{l}\frac{1}{8} \\
\dot{0}\end{array}$} & \multirow{5}{*}{$\begin{array}{c}\text { Null } \\
\text { Hyp } \\
\text { othe } \\
\text { sis } \\
\text { Reje } \\
\text { cted }\end{array}$} \\
\hline & $\mathrm{Ug}$ & Grou & 05 & & & & \\
\hline & $\mathrm{Pg}$ & ps & & & & & \\
\hline & $\begin{array}{l}\text { diplom } \\
\text { a level }\end{array}$ & $\begin{array}{c}\text { Withi } \\
\text { n }\end{array}$ & \multirow{2}{*}{$\begin{array}{c}1014 . \\
9\end{array}$} & & \multirow{2}{*}{$\begin{array}{c}8.119 \\
16\end{array}$} & & \\
\hline & Others & $\begin{array}{c}\text { Grou } \\
\text { ps }\end{array}$ & & & & & \\
\hline
\end{tabular}

\section{Source: primary data}

Hencethe $(\mathrm{P})$ value is - (0.086)null hypothesis is accepted andthere is no significance different betweenrespondentsincome towards homeopathy treatment taken.

Hence the $(\mathrm{P})$ value is - $(0.02)$ null hypothesis is rejected and there is significance different between respondents age and homeopathy treatment taken.

Hence the $(\mathrm{P})$ value is - $(0.03)$ null hypothesis is rejected and there is significance different between respondents'educational qualificationand homeopathy treatment taken.

\section{WEIGHTED AVERAGE METHOD}

\begin{tabular}{|c|c|c|c|c|}
\hline S.No & Particulars & $\begin{array}{c}\text { Total } \\
\text { score }\end{array}$ & $\begin{array}{c}\text { Weighted } \\
\text { Average score }\end{array}$ & Rank \\
\hline 1 & It is cheaper & 364 & 2.8 & V \\
\hline 2 & Quick relief & 419 & 3.22 & IV \\
\hline 3 & $\begin{array}{c}\text { No side } \\
\text { effects }\end{array}$ & 433 & 3.33 & III \\
\hline 4 & $\begin{array}{c}\text { Less } \\
\text { consulting } \\
\text { time }\end{array}$ & 446 & 3.43 & II \\
\hline 5 & $\begin{array}{c}\text { Natural } \\
\text { medicine }\end{array}$ & 470 & 3.61 & I \\
\hline
\end{tabular}

Source: Primary Data

The over table shows the consumer satisfaction towards homeopathy treatment among general public. From the analysis the highest weightage is for Natural medicine (3.61), which are followed by Less consulting time (3.43), No side effects (3.33), Quick relief (3.22), It is cheaper (2.80). It is very interesting to note that first three highest score given for natural medicine, less consulting time and no side effects. The result concludes that the respondents were contributingtowardsnatural medicine. 


\section{FINDINGS}

It is found that $65 \%$ of the respondents are male, $37 \%$ of them are in age group of $25-30$ years, $29 \%$ of the respondents completed post graduate and $29 \%$ of the respondents completed diploma, $37 \%$ of the respondents family monthly income is between Rs.30000 - Rs. 40000, $51 \%$ are married, $56 \%$ of the respondents are from rural area. From ANOVA test it is found that there is no significance difference between respondents income towards homeopathy treatment taken. There is significance difference between respondents age and homeopathy treatment taken. There is significance difference between respondents' educational qualification and homeopathy treatment taken. It is noted from the weighted average method first three highest score given for natural medicine, less consulting time and no side effects.

\section{SUGGESTIONS}

Homeopathy medicine is becoming familiar among the general public especially young generation. The government has to take steps to increase homeopathy clinics in rural and urban areas. They have to take initiatives to conduct awareness program and medical camps.

\section{CONCLUSION}

Now - a - days most of the people prefer alternate medical practices. There are more programs being conducted by the concerned clinics and hospitals regarding their medical practices. Most of the representatives approach the public thatalternate medicines such as homeopathy, ayurveda, unani and siddha has no side effects. This study is carried out to analyze whether homeopathy practice have reached the public and their satisfaction regarding homeopathy medicines. The media should contain interviews of homeopathy medicines. The government should create more awareness about traditional medicines to the public and it is very important to the future generation.

\section{ACKNOWLEDGEMENT}

The authors acknowledge and thank the Indian Social Sciences Research Council (ICSSR) for providing doctoral scholarship. I convey my sincere thanks to all those who have been connected with this project and have helped me with that and made it a valuable experience.

\section{REFERENCE}

1. AYUSH, M. O. (2016, 02 25). Government of India. Retrieved from http://ayush.gov.in: systems/homoeopathy/introduction-homoeopathy

2. Birgit, O. ( 2010, October). Health24. Retrieved from Health24: https://www.health24.com/Natural/Natural-living/Homeopathy-a-giftor-con-20120721

3. Biesok, G. (2017). Customer satisfaction - Meaning and methods of measuring Customer Satisfaction - Meaning And Methods Of Measuring, (June 2011).

4. Coshall, J., \& Combe, I. (2006). Evaluating service quality and consumer satisfaction in emerging markets, (November), 582-590. https://doi.org/10.1111/j.1470-6431.2005.00484.x

5. Devid, B. (2014). Consumer Satisfaction in the Healthcare Sector . A Critical Review of Some Empirical Studies by, 4(2), 168-178.

6. Dnsc, L. D. (2019). Patient Satisfaction Measurement : Current Issues and Implications, 6(3), 9000.

7. Giese, J. L., \& Cote, J. A. (2014). Defining Consumer Satisfaction, (September).

8. Hsu, C., Cherkin, D. C., Hoffmeyer, S., Sherman, K. J., \& Philips (2012). Patient and clinician openness of including a broader range of healing options in primary care. The Annuals of Family Medicine.

9. Jaggi, R., \& Ghosh, M. (2017). Consumer Perception of Patanjali Products:An Analytical Study. The IUP Journal of Brand Management, 14 (1), 13-24.

10. Kochkin, B. S. (2000). MarkeTrak V : Consumer, 53(1).

11. Mcmahon, R. J., \& Forehand, R. L. (2019). Consumer satisfaction in behavioral treatment of children: Types, issues, and recommendations, (77), 4-5.

12. Newsome, P. R. H., \& Wright, G. H. (1999). A review of patient satisfaction : 1 . Concepts of satisfaction, 186(4), 161-165.

13. Naicker, S. (2008). A survey of medical specialists perceptions and interactions with Homoeopathy. Durban: M.Tech: (Hom) dissertation, Durban University of Technology.

14. Riley, D., Fischer, M., Singh, B., Haidvogl, M., \& Heger, M. (2001). Homoeopathy and conventional medicine: an outcomes study comparing effectiveness in a primary setting. The journal of alternative and complementary medicine, 7 (2), 149-159.

15. Roy, V. (2015). Time to sensitize medical graduates to the Indian Systems of Medicine and Homeopathy. The Indian Journal of Pharmacologyol, 47 (1), 1-3.

16. Shaffer, T. R., \& Sherrell, D. L. (n.d.). Consumer Satisfaction with Health-Care Services: The Influence of Involvement, 14(May 1997), 261-285.

17. Surywanshi, A., \& Maharshi, S. (2013). Talent management: Success Mantra for Small and Medium sized Enterprises. Industrial Engineering Letters, 3 (11), 54-49.

18. Yoganandan, G., \& Vetriselvan, V. (2017). A Study on Public Awareness and Perception Towards Homeopathy Medicine in India. North Asian International Research Journal of Social Science \& Humanities, 3 (12), 287-291.

\section{AUTHORS PROFILE}

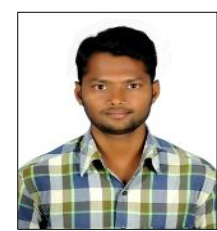

Biographical notes: V. Vetriselvanis a Ph.D research scholar Department of Management Studies, Periyar University, Salem, Tamil Nadu, India. He completed his SSLC and Higher secondary in Government Higher secondary school, Mallur. He pursued his B.B.A. Bachelor of Business Administration in April 2013 from Mahendra Arts and Science College, Namakkal, affiliated to Periyar University, Salem, He completed the diploma in computers and office management (DCM). M.B.A Master of Business Administration in April 2015 from Sona College of Technology, affiliated to Anna University and pursuing Doctor of Philosophy in Management Studies from November 2015 in Periyar University, Salem. His Areas of Specialisation is Marketing and Human resource management. He has published 5 articles in peer UGC CARE Journals and three in Conference proceedings. He has presented 17 papers in conferences and seminars. He has participated in 12 workshops. He has been awarded University Research Fellowship (URF) for the year 2016-2018 and Indian Council for Social Science Research (ICSSR) Doctoral Fellowship for the year 2018 2020. His paper has been accepted in SSCI journal and two papers in Scopus indexed journals.

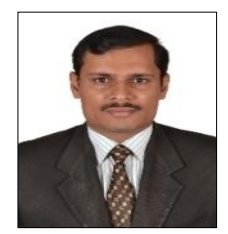

Biographical notes: G. Yoganandanis Associate Professor at Department of Management Studies, Periyar University, Salem, Tamil Nadu, India. $\mathrm{He}$ pursued his B.Sc Bachelor of Science (Chemistry) in April 1997 from Erode Arts College, Erode, affiliated to Bharathiar University, Coimbatore and Doctor of Philosophy in Management Studies in April 2014, from Anna University, Chennai. His Area of Specialisation is Marketing, International Marketing and Entrepreneurship. $\mathrm{He}$ has published 59 articles in peer-reviewed international journals. He has over 18 years of experience in teaching $\&$ research and 2 years experience in textile export industry. His current area of research includes rural marketing, international marketing and entrepreneurship. He has guided 23 M.Phil scholars. Currently, he is guiding one Post Doctoral Fellow, 5 Ph.D research scholars while 2 research scholars have submitted their $\mathrm{Ph}$. D thesis. 
He has completed a Major Research Project funded by Rajiv Gandhi National Institute of Youth Development, Sriperumpudur and an ongoing Major Research Project funded by ICSSR (under IMPRESS Scheme), New Delhi. He has presented 53 research papers national and international seminars and has acted as Chair person in 4 international conferences. He has given guest lecturers in more than 20 forums. He have participated in 11 FDPs and organized 15 programmes. He has received two awards for teaching and research. He has visited University of Kelaniya, Sri Lanka for International Conference. 